\title{
Plant macrofossils analysis from Steregoiu, NW Romania: taphonomy, representation, and comparison with pollen analysis
}

\author{
Angelica FEURDEAN1* and Ole BENNIKE ${ }^{2}$ \\ ${ }^{1}$ School of Geography, Centre for the Environment, University of Oxford, South Parks Road, Oxford, OX1 3QY, UK \\ Quaternary Research Group, Department of Geology, „Babeş-Bolyai” University, Kolgălniceanu 1, 400084, Cluj, Romania \\ ${ }^{2}$ Geological Survey of Denmark and Greenland, Øster Voldgade 10, DK-1350 Copenhagen, DK, Denmark
}

Received November 2007; accepted July 2008

Available online 25 August 2008

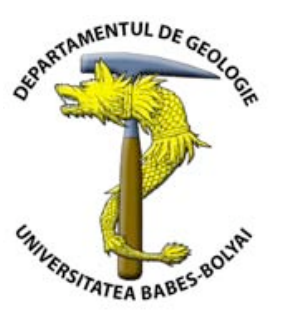

\begin{abstract}
This paper presents the results of macrofossil analysis from Steregoiu sequence in the Gutâiului Mountains covering the last 8,000 cal BP. The studied peat deposit is characterized by abundant macrofossils. Their diversity is, however, low with most remains coming from plants that grew on the mire and in the forest surrounding the basin (Carex spp., Cyperus sp., Urtica dioica, Potentilla erecta, Filipendula ulmaria, Rubus idaeus, Lycopus europaeus). The concentration of Picea abies macrofossils correlates partially well with its pollen percentages, and only when it has apparently been present on the bog surface. The absence of macrofossils from deciduous trees, which were abundant in the surrounding vegetation according to the pollen data, suggests that these deciduous trees taxa were not growing on the bog or around its margins. The combined macrofossil and the pollen results assists in the understanding of the differences between the local and regional flora.
\end{abstract}

Key words: plant macrofossil, production, preservation, taphonomy, pollen, Romania.

\section{INTRODUCTION}

Plant macrofossil analysis has been used to reconstruct past flora and vegetation since the $19^{\text {th }}$ century (Steenstrup, 1842; Reid, 1899; Watts, 1978; Birks, 1973, 2001; Wasylikowa, 1967; Hannon, 1999). Pollen analysis was developed during the early part of the $20^{\text {th }}$ century (von Post, 1916; Fægri and Iversen, 1975; Beug, 1977; Reille, 1992), and it became the most widely applied method to investigate past vegetation dynamics. Applied independently in paleoecological studies, each of the two methods has their own advantages and limitations, which can be refined when used together.

Firstly, the two methods complement each other in improving taxonomic resolution of a fossil record. The main advantage of plant macrofossil analysis is that it can be used to identify at a low taxonomic level (i.e., species), and therefore can provide more precise information on past flora, vegetational and climatic changes (Birks and Birks, 1980). On the contrary, pollen analysis often only allows identification at higher taxonomical levels (i.e., family and genera).

Secondly, the two techniques address different spatial scales. Plant macrofossils are large, have low dispersal capacity, and therefore are more closely deposited to the parent plants. However, as lake and mire deposits are often investigated, macrofossils from aquatic and wetland species tend to be over-represented, whereas macrofossils of terrestrial taxa are under-represented in fossil assemblages (Birks, 1980, 2001, 2003; Wainman and Mathewes, 1990; Dieffenbacher-Krall, 2007; Jackson and Booth, 2007).
Because plant macrofossils are not efficiently mixed and transported, the absence of a macrofossil type in a fossil assemblage does not necessarily imply the absence of its parent plant in the surrounding vegetation (Birks and Birks, 1980). The presence of a macrofossil in sediments is a very strong indicator of the local presence of that species. This small-scale vegetation reconstruction can hardly be achieved using pollen analysis alone, as the most of the pollen grains are produced in larger quantities, have better dispersal capability. Consequently, pollen studies offer a more complete picture of the surrounding past vegetation and at a different scale varying from local to regional.

Despite the fact that the two proxies complement each other so well, only in the last few decades the number of studies that use them in tandem to address paleoecological questions increases. For Romania, Wohlfarth et al. (2001) first combined plant macrofossil and pollen analyses of dated sedimentary sequence from the site Preluca Tiganului, situated in the Gutâiului Mountains. This work that covers the interval 15,000-13,600 cal BP was followed by analyses from a neighboring site, Steregoiu on the time spanning between 15,000 and 8,000 cal BP (Feurdean and Bennike, 2004). The macrofossil analysis at the two sites revealed several new aspects for the Lateglacial flora and climate in Romania such as: (i) the presence of three species of pine (Pinus mugo, Pinus sylvestris and Pinus cembra); (ii) the abundance and extension of Picea abies woodlands in the Carpathians may have been larger than was assumed from pollen analysis alone (Feurdean et al., 2007); (iii) provide 
important information on the past natural biodiversity showing the presence of taxa that have low pollen production, produce pollen grains that are sensitive to corrosion or cannot be identify at species level (e.g., Larix decidua, Populus tremula, Dryas octopetala, Rubus idaeus, Prunus padus, Ceratophyllum demersum, Menyanthes trifoliata, Campanula latifolium, Comarum palustre, Potamogeton obtusifolum, P. alpinus, etc).

This paper presents the results of macrofossil analysis from the Steregoiu sequence in the Gutâiului Mountains, NW Romania covering the period from 8,000 cal BP to present. The macrofossil data are then compared with previously published macrofossil from the same basin. We discuss the influence of the surrounding vegetation on the accumulation of various macrofossils and explore how the sediment type, basin size and coring point location have affected the composition of the macrofossil assemblages throughout the time.

\section{SITE DESCRIPTION}

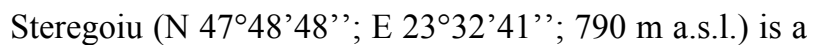
former crater lake situated in the Gutâiului Mountains, Eastern Carpathians (Björkman et al., 2003) (Fig. 1). The site has an elongated surface area of ca. 0.5 ha and is surrounded by fairly steep slopes (Fig. 2). It is an eutrophic to mesotrophic mire with an open vegetation composed of different species of grasses, sedges and herbs. The surrounding forest is dominated by beech (Fagus sylvatica). Stands of Picea abies were also noted in the vicinity of the basin, and of Carpinus betulus, Tilia cordata, Corylus avellana, Quercus petraea, Fraxinus excelsior, Ulmus minor occur in the regional woodland.

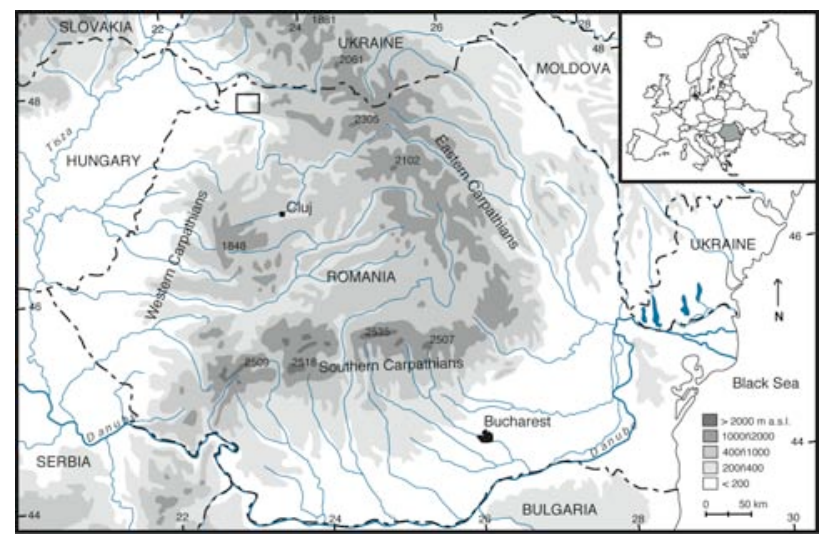

Fig. 1. Map showing the location of study area (black square) in NW Romania.

\section{METHODS}

Cores were collected with a Russian corer ( $1 \mathrm{~m}$ length, 5 $\mathrm{cm}$ diameter) from the central, deepest part of the site in May 1999. The lithology comprises carr peat between 1.25 and $2.50 \mathrm{~m}(8,000-3,500$ cal BP) and fen peat for the remainder period (Fig. 3 ).

Contiguous, $4 \mathrm{~cm}$ samples of ca. $100 \mathrm{ml}$ were extracted, soaked in $5 \% \mathrm{NaOH}$ and sieved through a $0.25 \mathrm{~mm}$ mesh under running water. All recognizable macro remains were extracted and examined under a dissecting microscope. The fossil identification was carried out using atlases and keys of Katz et al. (1965). The macrofossil diagram was constructed Studia UBB, Geologia, 2008, 53 (1), 5 - 10 with the TILIA program (Grimm, 1992) and visually subdivided into macrofossil assemblage zones. They are presented along with several representative pollen taxa to provide complementary information about past floristic and vegetation composition (Fig. 3).

Seven ${ }^{14} \mathrm{C}$ AMS measurements were performed on terrestrial plant macrofossils and presented in Björkman et al. (2003). In the present study the ${ }^{14} \mathrm{C}$ AMS radiocarbon ages were calibrated with the programme CALIB 5.0.2 (Stuvier et al., 2005), using the IntCal04 data set (Reimer et al., 2004). The age depth model follows a linear interpolation between the mid point of the calibrated dates at 2 sigma.

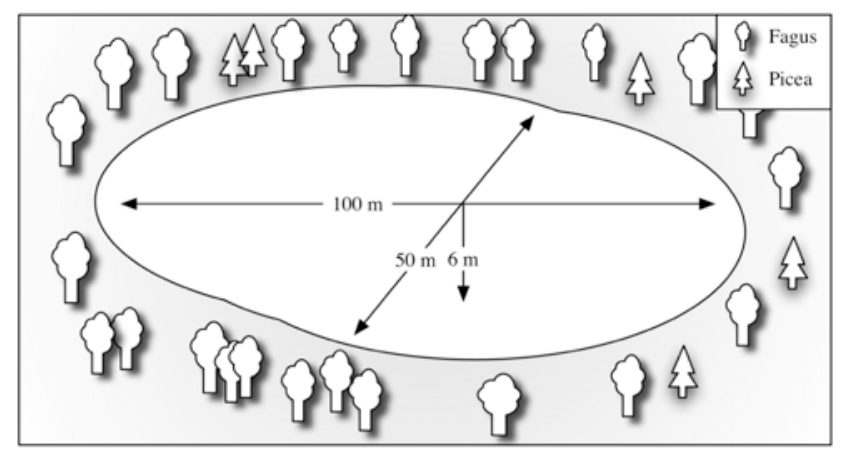

Fig. 2. Sketch of the Steregoiu site showing the composition of surrounding forest, the shape, size (ca. $100 \mathrm{~m}$ long, $50 \mathrm{~m}$ wide), and depth of the basin (6 $m$ below the bog surface) at the coring point.

\section{RESULTS}

The macrofossil record presented in this study covers the last 8,000 cal B.P (Fig. 3), and the characteristics of each macrofossil assemblage zone are shortly presented below.

S1 (2.30-1.90 m; 8,000-7,500 cal BP). Picea abies needles are abundant throughout the whole zone. The telmatic flora comprises fairly high numbers of Carex spp. and a few Cyperus sp. nutles. Rubus idaeus and Lycopus europaeus seeds are rare. Cenococcum geophilum sclerotia are abundant in two samples, whereas radicells are scarce.

S2 (1.90-1.55 m; 7,500-5,500 cal BP). This zone is characterized by a very low number of macro-remains. A few remains of Carex spp. nuts are recorded throughout this zone. Cenococcum geophilum sclerotia appear in two samples, whereas radicells increase slightly.

S3 (1.55-1.18 m; 5,500-3,700 cal BP). Picea abies needles show a fairly high number and increase in abundance in the upper part of the zone. Carex spp., Urtica dioica, Rubus idaeus and Filipendula ulmaria seeds are rare. Cenococcum geophilum sclerotia has maximum in the middle part of this zone, whereas radicells are only present in low numbers.

S4 (1.18-0.52 m; 3,700-1,500 cal BP). Picea abies needles disappear completely from the profile. Carex spp. and Cyperus sp. nuts became abundant and have short-lived maxima. Lycopus europaeus is present with few seeds, Cenococcum geophilum sclerotia are rare, and radicells become more common.

S5 (0.52-0.00 m; 1,500 cal BP to present). Potentilla erecta seeds appear abundantly at the beginning of this zone, where a fairly high number of Carex spp. nuts are also recorded. Radicells decrease towards the second half of this zone. 


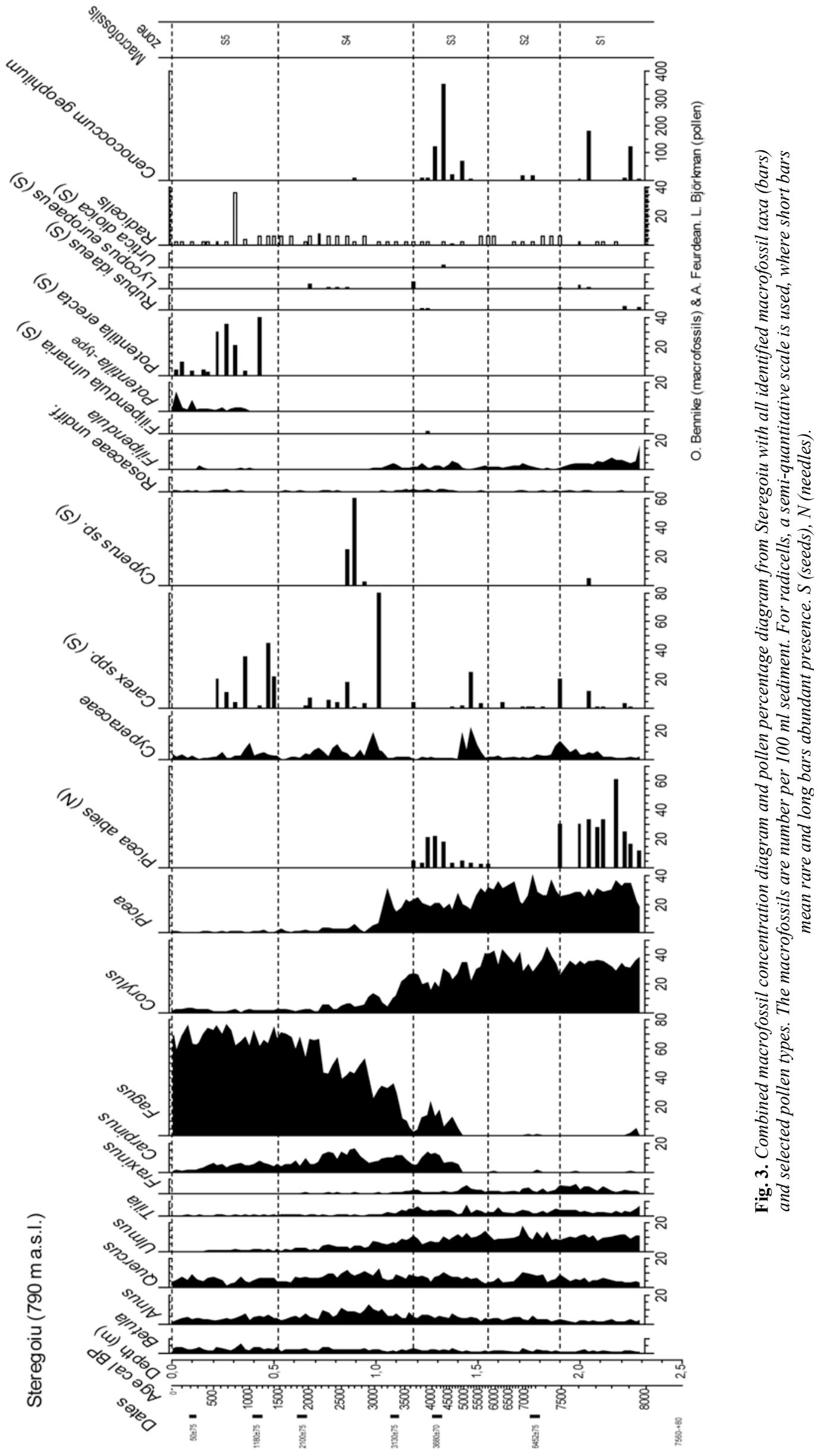




\section{INTERPRETATION}

The abundant presence of Picea abies macrofossils between 8,000 and 7,500 cal BP (S1) indicates that it was important on local vegetation e.g., grew on the bog surface or close to the margins (Fig. 3). The corresponding high pollen percentages for Picea abies and for several deciduous trees such as Corylus (dominating), Quercus, Tilia, Fraxinus, Ulmus, Alnus, Betula, Pinus, Salix and Sambucus, suggest that the floristic composition of this woodland was much more diverse than is illustrated by the macrofossil record (Fig. 3). Herbaceous plants characteristic of lake margin and wetland in lakes surrounded by deciduous and coniferous forests i.e., Rubus idaeus, Lycopus europaeus, Urtica dioica, Carex spp. and Cyperus sp., were also present.

Macrofossils of Picea abies disappeared during the following interval (7,500 and 5,500 cal BP; S2), whereas pollen values for Picea abies and for most of the other deciduous tree species remained fairly constant (Fig. 3). Studies on Picea pollen production, dispersal, transport and representation have shown that long distant transported pollen rarely exceeds 5\% (Huntley and Birks, 1983; Hicks, 1994). Therefore, pollen percentages of $25 \%$, even in the absence of macrofossils suggest that Picea abies was still an important taxon in the upland vegetation of Steregoiu, but most probably it has disappeared from the bog surface and its margins (Fig. 3). The deposition of highly decomposed peat indicates that the dry environment may have led to strong biodegradation of all macrofossils.

Picea abies macrofossils are again present in fairly high numbers between 5,500 and 3,700 cal BP (S3). This coincides with a slight decrease in its pollen percentage values and with an increase in the pollen percentage values of Alnus, Betula and of Cenococcum geophilum sclerotia, a fungus that normally occurred in dry peat bog. This development could indicate a change towards a drier bog surface that allowed the expansion of wet loving woody species over the bog. The peat surface was overgrown by Carex spp., Rubus idaeus and Filipendula ulmaria. In the upland vegetation, the appearance and expansion of Carpinus and Fagus seems to have reduced the representation of Picea and Corylus. Herbaceous taxa characteristic of wetlands and field layer of the forest surrounding the basin (Rubus idaeus, Lycopus europaeus, Filipendula ulmaria, Urtica dioica, Carex ssp. and Cyperus sp.) appear to have been common.

From about 3,500 cal BP ago, Picea abies macrofossils are absent, and 100 years later this corresponds with a decrease in pollen percentages, suggesting that Picea abies was no longer co-dominant in the upland vegetation nor on the peat surface (S4, S5; Fig. 3). The marked decline of Picea abies coincides with the decline of most of the other deciduous trees (Corylus, Tilia, Fraxinus and Ulmus), and with the massive expansion of Fagus sylvatica. Cenococcum geophilum sclerotia are virtually absent during this time interval, which may be an indication of a wetter peat surface condition. This assumption may be supported by the abundant occurrence of nutles of Carex spp. and Cyperus sp, taxa indicator of fen communities generally requiring wetter peat surface conditions. Over the last 1,200 years, Potentilla erecta grew abundantly on the wetland surface or at least at the coring point.

At present, Fagus sylvatica woodland dominates the surrounding slopes and encircles the basin. Isolated stands of fairly young (ca. 30-50 years) planted Picea abies are found. The absence of peak in the pollen curve of Picea abies in its uppermost part of the profile indicates that the period of spruce plantation is not present in the diagram.

\section{THE INFLUENCE OF DEPOSITIONAL ENVIRONMENTS ON THE MACROFOSSIL REPRESENTATION}

The present results are compared with previously published macrofossil record from the same basin covering the time interval 15,000 and 8,000 cal BP in order to discuss the influence of the surrounding vegetation on the accumulation of various macrofossils and to explore how the sediment type, basin size and coring point location have affected the composition of the macrofossil assemblages.

Picea abies is the only tree species of which macrofossils were found after 8,000 cal BP at Steregoiu. The macrofossils of deciduous trees are completely absent, though they were continuously recorded by pollen (Fig. 3). A more diverse terrestrial flora with coniferous and deciduous trees and shrub species alongside with a rich limnic and telmatic flora was found between 15,000 and 10,500 cal BP (Feurdean and Bennike, 2004). Such low diversity of macrofossils over the last 8000 years compared to the previous interval may be explained by the change in the sedimentary setting. The depositional basin developed from an initial lake phase to a bog from around 10,500 cal BP. In lake sediments, macrofossils from a mixed origin (aquatic, mire, local and distal terrestrial) are more likely to occur, whereas in peat deposits macrofossils are generally dominated by local plants growing on their surface (Birks, 1980). Shallow water over the wetlands and peat surface limits the spread of macrofossils from the surrounding upland vegetation and they are restricted to plant organs that are well dispersed by wind e.g., winged seeds, bud scales, samaras and small needles (Birks, 1980; Jackson and Booth, 2007). Furthermore, the marsh and wetland vegetation acts as filter for the macrofossils of upland taxa. Consequently, upland plants with such dispersal mechanisms i.e., Betula, Salix, Picea tend to be better represented in the fossil macrofossil assemblage from peat deposits. Modern macrofossil studies show that macrofossil samples may contain 4 out of 14 tree species or 10 out of 16 shrub species (Wainman and Mathewes, 1990), or it can drop to $2 \%$ of the species list derived from the surrounding vegetation (Allen and Huntley, 1999).

The poor representation of upland plants in the macrofossil record at Steregoiu could also be because the sediment cores used for pollen and plant macrofossil analyses were collected from the central deepest part of the former lake. It is well documented that this approach is best for pollen analysis but it usually restricts the amount of macrofossils, which are better recorded in cores taken near shores (Birks, 1973, 2003; Wainman and Mathewes, 1990; Jackson and Booth, 2007). Small, deep lakes with sloping shores can, nevertheless, preserve high amounts of macrofossil also in the central part of the lake (Watts, 1978). As Steregoiu is a small basin ( 0.5 ha) with rather steep surrounding slopes, we could assume that the macrofossil influx would be good even in the centre. This proved to be true for the time when the basin was a lake (Feurdean and Bennike, 2004). During the lake phase plant remains could 
have more easily been transported to the centre of the basin. Once the lake became overgrown, and carr/fen peat developed, the influx of non-local plant macrofossils was lowered, and therefore the plant macrofossils represent the local taxa.

Besides the fact that the macrofossils of upland deciduous trees are unlikely to reach the sedimentary basin at Steregoiu, they are also very susceptible to decay. The leaves of deciduous tree are non-durable, composed of highly biodegradable material and, consequently, strongly underrepresented or often absent in macrofossil assemblages (Collinson, 1983; Birks, 1973; Burnham et al., 1992). The degradation is related to the depositional environment, being lower in lakes, deltas or streambeds where the incoming plant remains are rapidly buried (Birks, 1980). The accumulation of peat with a relatively low depositional rate at Steregoiu during the last 8,000 years may have lead to strong biodegradation and this may account for the absence of leaves of deciduous trees (Fig. 3). This assumption is supported by the record of durable coniferous needles and seeds of extra local taxa such as Picea abies, Carex spp., Cyperus sp., Urtica dioica, Potentilla erecta, Filipendula ulmaria, Rubus idaeus, Lycopus europaeus.

\section{CONCLUDING REMARKS}

The macrofossil assemblages at Steregoiu show a low diversity of macrofossils for the last 8,000 cal BP, with high representation of plants growing on the peat surface and in the field layer of forest surrounding the basin (Carex spp., Cyperus sp., Urtica dioica, Potentilla erecta, Filipendula ulmaria, Rubus idaeus, Lycopus europaeus). Macrofossils of Picea abies correlate partially with its pollen percentages and only when it seems to have been present on the peat surface. The complete lack of macrofossils of deciduous trees, even though the pollen record indicates a continuous presence of several species, point to taphonomic reasons for the absences of these macrofossils in the sediments. Therefore, the depositional environment appears to have strongly influenced the accumulation and representation of various macrofossils. The filter effect of very local vegetation and the high decay ratio for leaves from deciduous trees combined with evidence for a slow peat accumulation during this time may account for the absence of upland plants macrofossils in general and of deciduous trees in particular.

Acknowledgments. The financial support for preparation of this manuscript came from Marie Curie grant to AF (MEIFCT-2006-024296). Manu Black and Anneli Ekblom are kindly thanked for suggestion on the earlier version of the manuscript. Constructive comments from the two anonymous reviewers are greatly acknowledged.

\section{R E F E R E N C E S}

Allen, J.R.M., Huntley, B. 1999, Estimating past floristic diversity in montane regions from macrofossil assemblages. Journal of Biogeography, 26: 55-73.

Birks, H.H. 1973, Modern macrofossil assemblages in lake sediments in Minnesota. In: Quaternary Plant Ecology (Birks, H.J.B., West, R.G., Eds.). Blackwell, Oxford, p. 173-189.
Birks, H.H. 1980, Plant macrofossils in Quaternary lake sediments. Archiv für Hydrobiologi, 15: 1-60.

Birks, H.H. 2001, Plant macrofossils. In: Tracking environmental change using Lake sediments Vol. 3: Terrestrial, Algal and Siliceous Indicators (Smol, J.P., Birks, H.J.B. \& Last, W.M., Eds.). Kluwer Academic Publisher, Dordrecht, p. 49-74.

Birks, H.H. 2003, The importance of plant macrofossils in the reconstruction of Lateglacial vegetation and climate: examples from Scotland, western Norway and Minnesota USA. Quaternary Science Reviews, 22: 453-473.

Birks, H.J.B., Birks, H.H. 1980, Plant Macrofossils. Quaternary Palaeoecology. Edwards Arnold London, p. 66-84.

Björkman, L., Feurdean, A. \& Wohlfarth, B. 2003, Lateglacial and Holocene forest dynamics at Steregoiu in the Gutâiului Mountains, NW Romania. Review of Palaeobotany and Palynology, 124: 79-111.

Burnham, R. J., Wing, S.L. \& Parker, G.G. 1992, The reflection of deciduous forest communities in leaf litter: implication for autochthonous litter assemblages from the fossil record. Paleobiology, 18: 30-49.

Collinson, M.E. 1983, Accumulation of fruits and seeds in three small sedimentary environments in southern England and their palaeoecological implications. Annals of Botany, 52: 583-592.

Dieffenbacher-Krall, A.C. 2007, Surface samples, taphonomy, representation. In: Encyclopedia of Quaternary Science (Elias, S.A., Ed.), Elsevier, p. 2367-2374.

Faegri, K., Iversen, J. 1975, Textbook of pollen analysis. $3^{\text {rd }}$ ed., Blackwell, Oxford.

Feurdean, A., Bennike, O. 2004, Late Quaternary palaeoecological and palaeoclimatological reconstruction in the Gutâiului Mountains, NW Romania. Journal of Quaternary Science, 19: 809-827.

Feurdean, A., Wohlfarth, B., Björkman, L., Tanțău, I., Bennike, O., Willis, K.J., Fărcaş, S. \& Robertsson, A.M. 2007, The influence of refugial population on Lateglacial and early Holocene vegetational changes in Romania. Review of Palaeobotany and Palynology, 145: 305-320.

Grimm, E.C. 1992, Tilia and Tilia-graph: Pollen spreadsheet and graphics programs. Programs and Abstracts, $8^{\text {th }}$ International Palynological Congress. Aixen-Provence, France, p. 52.

Hannon, G.E. 1999, The use of plant macrofossils and pollen in the palaeoecological reconstruction of vegetation. $\mathrm{PhD}$ thesis SILVESTRIA 106, Swedish University of Agricultural Science.

Hicks, S. 1994, Present and past pollen records of Lapland forests. Review of Palaeobotany and Palynology, 82: 17-35.

Jackson, S.T., Booth, R.K. 2007, Using plant macrofossils to refine and validate pollen studies In: Encyclopedia of Quaternary Science (Elias, S.A. Ed.), Elsevier, p. 2413-2442.

Katz, N.J., Katz, S.V. \& Kipiani, M.G. 1965, Atlase and keys of fruits and seeds occurring in the Quaternary deposits of the USSR. Nauka, Moscow (in Russian).

Reid, C. 1899, The origin of the British Flora. Dulau and Co., London.

Reille, M. 1992, Pollen et spores d'Europe et d'Afrique du nord. Laboratoire de botanique historique et palynologie, Marseilles.

Reimer, P.J., Baillie, M.G.L., Bard, E., Bayliss, A., Beck, J.W., Bertrand, C.J.H., Blackwell, P.G. Buck, C.E., Burr, Studia UBB, Geologia, 2008, 53 (1), 5 - 10 
G.S., Cutler, K.B., Damon, P.E., Edwards, R.L., Fairbanks, R.G., Friedrich, M., Guilderson, T.P., Hogg, A.G., Hughen, K.A., Kromer, B. McCormac, G., Manning, S., Ramsey, C.B., Reimer, R.W., Remmele, S., Southon, J.R., Stuiver, M., Talamo, S., Taylor, F.W., van der Plicht, J. \& Weyhenmeyer, C.E. 2004, "IntCal04 Terrestrial Radiocarbon Age Calibration, 0-26 cal kyr BP". Radiocarbon, 46: 1029-1058.

Steenstrup, J.J.S. 1842, Geognostisk-geologisk Undersögelse af Skovmoserne Vidnesdam- og Lillemose i det nordlige Sjelland. Det Kongelige Danske Videnskabernes Selskabs Naturvidenskabelige og Mathematiske Afhandlinger, 9: 17-120.

Stuiver, M., Reimer, P.J. \& Reimer, R.W. 2005, CALIB 5.0. http://radiocarbon.pa.qub.ac.uk/calib/.

Tobolski, K., Ammann, B. 2000, Macrofossils as records of plant response to rapid Late Glacial climatic changes at three sites in the Swiss Alps. Palaeogeography, Palaeoclimatology, Palaeoecology, 159: 251-259. von Post, L. 1946, The prospect for pollen analysis in the study of the earth's climate history. New Phytologist, 45: 193-217.

Wainman, N., Mathewes, R.W. 1990, Distribution of plant remains in surface sediments of Marion Lake, southwestern British Columbia. Canadian Journal of Botany, 68: 364-373.

Wasylikowa, K. 1967, Late Quaternary plant macrofossils from Lake Zeribar, Western Iran. Review of Palaeobotany and Palynology, 2: 313-318.

Watts, W.A. 1978, Plant Macrofossil and Quaternary Palaeoecology, In: Biology and Quaternary Environments (Walker, D.G., Ed.), Australian Academy of Science, Canberra, p. 53-67.

Wohlfarth, B., Hannon, G., Feurdean, A., Ghergari, L., Onac, B.P. \& Possnert, G. 2001, Reconstruction of climatic and environmental changes in NW Romania during the early part of the last deglaciation $(15,000$ 13,600 cal years BP). Quaternary Science Reviews, 20: 1897-1914. 